\title{
Biochemical and histological hepatic changes of Nile tilapia Oreochromis niloticus exposed to carbaryl
}

\author{
P. Matos ${ }^{\text {a,b,e,* }}$, A. Fontaínhas-Fernandes ${ }^{\text {a,b }}$, F. Peixoto ${ }^{\text {a,c }}$, J. Carrola ${ }^{\text {a,b,e }}$, E. Rocha ${ }^{\text {d,e }}$ \\ ${ }^{a}$ UTAD_University of Trás-os-Montes and Alto Douro (UTAD), Apartado 1013, 5000-911 Vila Real, Portugal \\ ${ }^{\mathrm{b}}$ CETAV_CCntre for Technological, Environmental and Life Studies, Apartado 1013, 5000-911 Vila Real, Portugal \\ ${ }^{\mathrm{c}}$ CECAV-Centre for Animal Sciences and Veterinary, Apartado 1013, 5000-911 Vila Real, Portugal \\ d ICBAS-Institute of Biomedical Sciences Abel Salazar, Largo Professor Abel Salazar, 2, 4099-003 Porto, Portugal \\ ${ }^{\text {e } C I I M A R-I n t e r d i s c i p l i n a r y ~ C e n t r e ~ f o r ~ M a r i n e ~ a n d ~ E n v i r o n m e n t a l ~ R e s e a r c h, ~ R u a ~ d o s ~ B r a g a s, ~ 289, ~ 4050-123, ~ P o r t o, ~ P o r t u g a l ~}$
}

Received 19 December 2006; accepted 26 March 2007

Available online 31 March 2007

\begin{abstract}
The purpose of this study was to evaluate biochemical and morphological responses induced by carbaryl in the liver of Nile tilapia (Oreochromis niloticus) exposed during 21 days to sublethal concentrations $\left(0.25\right.$ and $\left.0.5 \mathrm{mg} \mathrm{L}^{-1}\right)$, testing also recover for 14 days in clean water, after 14 days exposure. The activities of the following enzymes were measured: superoxide dismutase (SOD), catalase (CAT), glutathione $S$-transferase (GST), glutathione reductase (GR), and reduced (GSH) and oxidized glutathione (GSSG). Globally, our data showed that exposure to carbaryl decreased the SOD, CAT, GR, and GST activities, except for the SOD and GST activities after 14 days exposure to $0.25 \mathrm{mg} \mathrm{L}^{-1}$. In contrast, after 14 days exposure the GR activity of the hepatic tissue from carbaryl-treated fish showed significant elevation in relation to the control. When fish were left to recover, a positive response was seen in the GSH and GSSG contents. The results of the recovery group suggest that the toxicity produced by carbaryl is reversible to some extent within 15 days. The liver histological analysis showed differences between fish concerning the cellular vacuolization degree (VD) of the hepatocytes. In fish exposed to carbaryl it was observed an increasing hepatocellular basophilia. No other histological alterations were observed when fish was exposed to carbaryl, except a few necrotic foci at day 7. The sections stained with PAS reaction showed that the vacuolization was always not due to glycogen deposits, thus suggesting lipid accumulation. The combined increased basophilia and glycogen depletion is a common, although non-specific, liver response to many toxicants. In short, this work shows a relation between histological and biochemical changes in liver and carbaryl exposure. The effects of carbaryl were observed at different concentrations.
\end{abstract}

(C) 2007 Elsevier Inc. All rights reserved.

Keywords: Oxidative stress; Tilapia; Oreochromis niloticus; Carbaryl; Liver; Histology

\section{Introduction}

The aquatic ecosystem is continuously being contaminated with toxic chemicals from domestic, industrial and agricultural activities. Pesticides are one of the major classes of toxic compounds used in agricultural activities, namely organophosphorous and carbamates [1]. Carbamates are systemic and contact pesticides used as substi-

\footnotetext{
${ }^{*}$ Corresponding author. Address: UTAD, Apartado 1013, 5000-911 Vila Real, Portugal. Fax: +351 259350560 .

E-mail address: pmatos@utad.pt (P. Matos).
}

tutes for organochlorine insecticides because of their high efficiency and low persistence in the environment [2]. Carbaryl (1-naphthyl- $N$-methyl carbamate) is a broad spectrum carbamate insecticide that is reported to have a low persistence in soil and water [3,4]. Carbaryl has been used for the control of pests in forestry and agriculture, as well as to control the crustacean predators of shellfish and aquatic weeds in bays and estuaries [5].

The biochemical parameters in fish are sensitive for detecting potential adverse effects and relatively early events of pollutant damage [6]. Thus, it is important that pollutant effects can be determined and interpreted to 
delineate mechanisms of pollutant action and possibly ways to mitigate adverse effects. A review of literature indicates that biochemical changes in fish under pesticide exposure were extensively reported [7-9]. However, it is relevant that data on the effects of the carbaryl using aquatic organisms as experimental models is not well-established [10-12].

This liver plays an important role in several vital functions of basic metabolism and it is also the major organ of accumulation, biotransformation and excretion of contaminants in fish, including degradation and bioactivation of pesticides $[13,14]$. The evaluation of biochemical and histological changes in fish liver has become an important tool for monitoring environmental exposure of fish to contaminants in experimental studies $[15,16]$. The exposure to contaminants in aquatic ecosystems can enhance the intracellular formation of reactive species of oxygen, which induce oxidative damage to biological systems $[17,18]$. Bagchi et al. [19] found that different classes of pesticides may induce in vitro and in vivo generation of reactive oxygen species (ROS), such as hydrogen peroxide, superoxide and the hydroxyl radical. Oxidative stress happens when an imbalance occurs between production and elimination of ROS. The ROS can be detoxified by an enzyme defense system, comprising superoxide dismutase (SOD), catalase (CAT), and selenium-dependent glutathione peroxidase (GPx), or non-enzymically systems by the scavenging action of reduced glutathione, while organic peroxides can be detoxified by the activity of glutathione $S$-transferase [20]. Several studies demonstrated that changes in the levels of antioxidant enzyme activities can be used as possible biomarkers in different aquatic organisms [21,22].

The lack of information on the effects of carbaryl on fish has prompted us to undertake this study. As to the target species, tilapia was chosen because it is a good biological model for toxicological studies due to diverse characteristics, namely their high growth rates, efficiency in adapting to diverse diets, great resistance to diseases and to handling practices, easy reproduction in captivity and prolific rate, and, finally, good tolerance to a wide variety of environmental conditions [23].

Hence, this study was undertaken to examine the effect of carbaryl on biochemical aspects of Nile tilapia Oreochromis niloticus, during exposure and after recovery in clean water. The liver histology and hepatic activities of SOD, CAT, glutathione $S$-transferase (GST), glutathione reductase (GR), and the amount of reduced (GSH) and of oxidized glutathione (GSSG) were measured in liver after experimental exposure to two sublethal concentrations of commercial grade carbaryl.

\section{Materials and methods}

\subsection{Fish and experimental design}

Nile tilapia $O$. niloticus (Bouaké strain) were originally obtained from the Institute Nationale de Recherche Agronomique (Rennes, France) and raised in the Aquacul- ture Station of the University of Trás-os-Montes and Alto Douro (UTAD, Portugal) for three generations. Fish were kept in $100 \mathrm{~L}$ recirculating tanks (water flow rate of $5 \mathrm{~L} \mathrm{~min}^{-1}$ ) filled with dechlorinated tap water. Water composition was in agreement with European Community instructions (84/449/EEC Directives, Annex 5). The water parameters were within the normal ranges: $\mathrm{pH} 7.1$; alkalinity $60 \mathrm{mg} \mathrm{HCO}^{3-} \mathrm{L}^{-1}$; conductivity $63 \mu \mathrm{S} \mathrm{cm}^{-1} ; 14 \mathrm{mg}$ $\mathrm{Na}^{+} \mathrm{L}^{-1} ; 2.3 \mathrm{mg} \mathrm{K}^{+} \mathrm{L}^{-1} ; 4.1 \mathrm{mg} \mathrm{Ca}^{2+} \mathrm{L}^{-1} ; 6.5 \mathrm{mg}$ $\mathrm{Mg}^{2+} \mathrm{L}^{-1} ; 19.5 \mathrm{mg} \mathrm{Cl} \mathrm{L}^{-1} ; 27 \mathrm{mg} \mathrm{NO}_{3}^{-} \mathrm{L}^{-1}$ (nitrate); $0.5 \mathrm{mg} \mathrm{NO}_{2}{ }^{-} \mathrm{L}^{-1}$ (nitrite); hardness $74.5 \mathrm{mg} \mathrm{CaCO}_{3} \mathrm{~L}^{-1}$; $6.2 \mathrm{mg}$ dissolved $\mathrm{O}_{2} \mathrm{~L}^{-1} ; 21 \mathrm{mg} \mathrm{CO}_{2} \mathrm{~L}^{-1} ; 0.1 \mathrm{mg} \mathrm{H}_{2} \mathrm{~S} \mathrm{~L}^{-1}$ (hydrogen sulfide); $0.7 \mathrm{mg} \mathrm{NH}_{4}^{+} \mathrm{L}^{-1}$ (ammonia); and $12 \mathrm{mg}$ suspended solids $\mathrm{L}^{-1}$. Supplemental aeration was provided to maintain dissolved oxygen near saturation, the temperature was kept at $25 \pm 1^{\circ} \mathrm{C}$ and the photoperiod controlled (12D:12L).

The experiments described comply with the Guidelines of the European Union Council (86/609/EU) and of the UTAD for the use of laboratory animals. The water quality parameters mentioned above were assessed at collection days during the experimental period, with no significant changes being observed. Adult male and female $O$. niloticus $(39.1 \pm 1.0 \mathrm{~g}$ of body weight and $12.8 \pm 1.3 \mathrm{~cm}$ of total length) were randomly distributed through 9 tanks of $100 \mathrm{~L}$, at a density of 12 animals per unit. Food was withheld from $24 \mathrm{~h}$ prior to the experiment. During the experiment fish were fed daily to visual satiation with a diet tested in a previous study [24].

Two groups were exposed (in triplicate) to 0.25 and $0.5 \mathrm{mg} \mathrm{L}^{-1}$ commercial carbaryl for 21 days; these served as the exposed groups. The higher level of exposure was one-third the $96 \mathrm{~h} \mathrm{LC50}$ concentration for commercial carbaryl. After 14 days of exposure period 12 fish were transferred to carbaryl-free water for 14 days to study the recovery response. A third group of 12 control fish was kept in toxicant free water. Both control and experimental tanks were water renewed $(90 \%)$ every two days. Sampling of exposed and control fish ( $n=6 /$ group) was done after 45 $\min$ (day 0 ), 7, 14, and 21 days after starting the experience. Tilapia were anaesthetized by immersion in a $0.2 \mathrm{ml} \mathrm{L}^{-1}$ aqueous solution of 2-phenoxyethanol (Sigma, Spain), and thereafter measured and weighed. Then, fish were rapidly killed by decapitation and the liver immediately removed and processed, one part being fixed for microscopy (see below), and other frozen for later assay of enzymes.

\subsection{Analytical techniques}

The activities of SOD, GR, and GST were measured in the hepatic cytosolic fraction from $O$. niloticus of all groups considered in this study. Livers were homogenised in ice-cold sodium phosphate buffer $50 \mathrm{mM}, \mathrm{Na}_{2}$ EDTA $0.1 \mathrm{mM}, \mathrm{pH}$ 7.8. The fractions were obtained after centrifugation at $10,000 \mathrm{~g}$ for $20 \mathrm{~min}$. SOD (EC.1.15.1.1) activity was assayed according to Paya [25], with minor 
modifications. The nitrotetrazolium blue chloride (NBT, Sigma N-6876) was used as detection molecule instead of cytochrome $c$. Assays were conducted in the presence of $100 \mathrm{nM}$ potassium phosphate buffer $(\mathrm{pH}$ 7.8), EDTA $10 \mathrm{mM}$, NBT $10 \mathrm{mM}$, hypoxanthine $10 \mathrm{mM}$ (Sigma H9377), and xanthine oxidase $0.023 \mathrm{U} \mathrm{mol}^{-1}$ (Sigma X4500). The reduction of NBT was measured at $560 \mathrm{~nm}$ and constant temperature $\left(25^{\circ} \mathrm{C}\right)$. The rate of NBT reduction in the absence of tissue was used as reference rate. One unit of SOD was defined as the amount of protein needed to decrease the reference rate to $50 \%$ of maximum inhibition. GR (EC 1.5.4.2) activity was measured by the method described by Carlberg and Mannervick [26] and Smith et al. [27]. This method was based on the absorbance decrease of NADPH at $340 \mathrm{~nm}$. Reaction solution contained buffer phosphate $200 \mathrm{mM}(\mathrm{pH} 7.5)$, Triton X$10010 \%$, DTNB $20 \mathrm{mM}$ (Sigma D-8130), NADPH $100 \mathrm{mM}$ (Sigma N-7505), and GSSG $200 \mathrm{mM}$ (Sigma G4376). The temperature of incubation was constant $\left(25^{\circ} \mathrm{C}\right)$. GST (EC 2.5 .1 .18 ) activity was measured according to Habig et al. [28]. Reaction mixture contained $2 \mathrm{~mL}$ of potassium phosphate buffer $100 \mathrm{mM}$, Triton X-100 $10 \%$, CDNB $100 \mathrm{mM}$ (Sigma C-6396), and GSH $100 \mathrm{mM}$ (Sigma G-4251). Reaction was started by adding sample, and absorbance at $340 \mathrm{~nm}$ at room temperature was monitored. The GST activity was expressed according to Uguz et al. [29]. Concentrations of GSH and GSSG were also measured in the hepatic cytosolic fraction by a fluorometric assay according the methodology described by Hissin and Hilf [30]. One molar Tris- $\mathrm{HCl}, 5 \mathrm{mM}$ EDTA ( $\mathrm{pH} 8.0$ ), $10 \mathrm{mM} \mathrm{H}_{2} \mathrm{O}_{2}$ were mixed and the rate of $\mathrm{H}_{2} \mathrm{O}_{2}$ consumption at $240 \mathrm{~nm}$ and $37^{\circ} \mathrm{C}$ was used for quantitative determination of CAT (EC 1.11.1.6) activity [31]. The protein content was determined according to Bradford [32], with bovine serum albumin as standard. All chemicals used in the enzymatic activity were of analytical purity and were obtained from Sigma Chemical Co.

\subsection{Histology}

When the liver was quickly dissected, $3 \mathrm{~mm}$ thick slabs were made. Some pieces were then fixed in Bouin's fixative for $24 \mathrm{~h}$ (at room temperature), dehydrated in ethanol, cleared in xylene, and embedded in paraffin. Histological sections ( $5 \mu \mathrm{m}$ thick) were cut and stained either with haematoxylin-eosin (H\&E) or with the periodic acid Schiff (PAS) reaction. In addition to the qualitative analysis, evaluation of the hepatocellular cytoplasm vacuolization degree was made using a semi-quantitative approach, according to the following five grades and general criteria [33]: Grade 0 (none) - absence of hepatocellular vacuolization; Grade 1 (low) —on average, $<25 \%$ of the hepatocyte cytoplasm shows vacuolization; Grade 2 (moderate) - on average, $25 \%<x<50 \%$ of the hepatocyte cytoplasm shows vacuolization; Grade 3 (high) - on average, $50 \%<x<75 \%$ of the hepatocyte cytoplasm shows vacuo- lization; Grade 4 (extreme) - $>75 \%$ of the cytoplasm (virtually total) is vacuolated.

\subsection{Statistical analysis}

Regarding biochemical data, differences among groups were tested by ANOVA followed by a Tukey's multiple comparison test at a 5\% significant level. Differences between vacuolisation degrees were tested by the non-parametric Kruskall-Wallis ANOVA and Mann-Whitney U tests. The Spearman's correlation non-parametric test was used for evaluating the strength of the relationship between pairs of variables. All tests were performed using the software STATISTICA 6.0 (StatSoft, Inc., 2001).

\section{Results}

\subsection{Biochemical analysis}

Neither mortality nor visible disease signals were observed in the fish exposed to sublethal concentrations of carbaryl. Changes in the activities of antioxidant enzymes in experimental fish are shown in Fig. 1. Exposure of tilapia $O$. niloticus to carbaryl alters the normal functioning of hepatic activity, by consistently decreasing the SOD, CAT, GR, and GST activities (except for SOD and GST activities after 14 days of exposure to the lower concentration, i.e., $0.25 \mathrm{mg} \mathrm{L}^{-1}$, as well as for GR activity also at 14 days of exposure to both concentrations). In fact, after 14 days of exposure the GR activity in carbaryl-treated fish showed significant elevation in relation to the control. Also, the GST activity in fish exposed to $0.25 \mathrm{mg} \mathrm{L}^{-1}$ at 14 days was significantly higher than in the other exposure time but not significantly higher than control value. It is notable that at day 0 fish exposed to carbaryl showed significant lower values in relation to control. The GSH/ GSSG ratio in hepatic tissue showed a decrease after carbaryl exposure (at 7 days) followed by an increase at the 14th (both concentrations) and $21 \mathrm{st}\left(0.25 \mathrm{mg} \mathrm{L}^{-1}\right)$ days. When fish were transferred into clean water, there was a recovery response, as revealed by the GSH and GSSG content. The SOD and CAT activities of the recovery group (RG) $\left(0.5 \mathrm{mg} \mathrm{L}^{-1}\right)$ were significantly higher when compared with the other exposure times, except for SOD when compared with the 14th day of exposure. The GSH content at 21 days and in the RG was significantly higher when compared with the other exposure days in both concentrations. Finally, concerning the GSSG content the lowest values were observed at 14 days, whereas the RG showed higher values.

\subsection{Histology}

The homogeneous parenchyma of $O$. niloticus liver from control fish (Fig. 2a) was composed of hepatocytes arranged in a typically complex three-dimensional architecture. Fish exposed to carbaryl (Fig. 2b-f) showed no histo- 

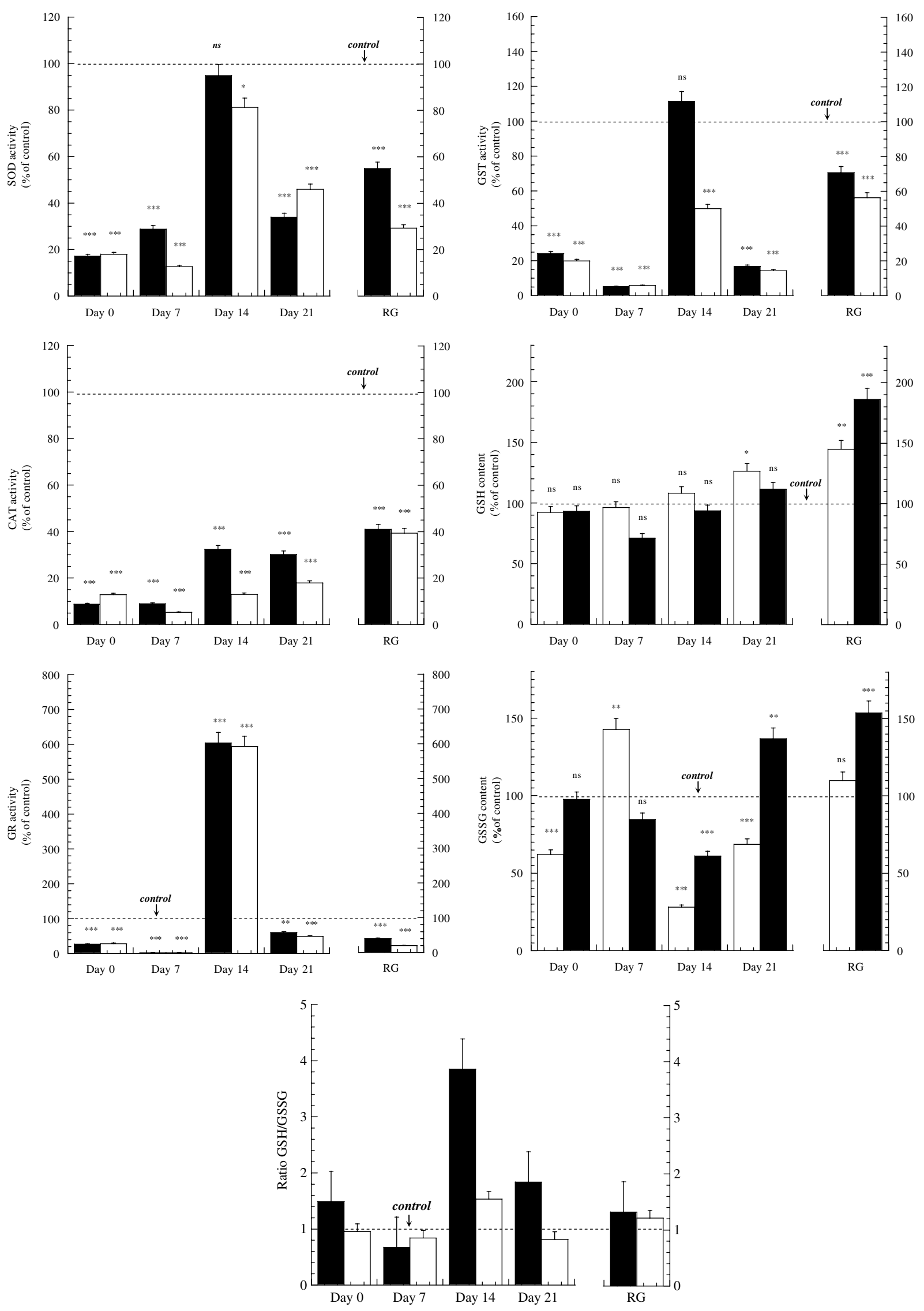
logical modifications, like inflammation or perceivable changes in the pool of pigmented macrophages. However, it was observed necrosis in fish exposed to carbaryl $\left(0.25 \mathrm{mg} \mathrm{L}^{-1}\right)$ at the 7 th day (Fig. 2c). The sections (overall weakly) stained with PAS reaction showed, indirectly, that the vacuolization was mainly due to lipid accumulation. Fig. $2 \mathrm{~g}$ represents the recovering group from fish exposed to $0.5 \mathrm{mg} \mathrm{L}^{-1}$, showing that the hepatocyte nuclei in the RG were more peripheric when compared to control group. The semi-quantitative analysis of the histological results suggests there are differences in the VD, as function of the day of exposure (Table 1). The VD was low at 7th and 14th days, whereas at 21 st and RG the values were similar to those of day 0 . No significant correlations between VD and GSH or VD and GSSG were observed.

\section{Discussion}

Pesticide-induced oxidative stress is the final manifestation of a multi-step pathway, resulting in an imbalance between pro-oxidant and antioxidant defence mechanisms [34]. Oxidative stress has been shown to be associated with exposure to several pesticides [35]. Herein, we studied the influence of carbaryl on toxicity related to oxidative stress. Despite that carbamate insecticide is reported to have a low persistence in water, very little is known about the toxic mechanism of carbaryl on aquatic organisms.

The results showed an effect of carbaryl on the enzymatic activities and in GSH and GSSG content in relation to control. It was also observed a decrease of enzymatic activity in relation to control group at day 0 in fish exposed to both concentrations of carbaryl. This decrease may derive from the sudden change in the fish environment, since they were moved from maintenance tanks with clean water to the aquaria with dissolved carbaryl. Although tilapia remained in these tanks for only $45 \mathrm{~min}$ before being sampled, the fact is that there was a quite rapid adaptative response to carbaryl exposure, compared to controls that did not show any change. There are indeed reports of very rapid gene transcription in fish after toxicant exposure, such as the case of CYPIA1 under the dioxin TCDD activation $[36,37]$.

The inhibition of CAT activity may be the result of $\mathrm{H}_{2} \mathrm{O}_{2}$ increase in the cell which can be generated directly by divalent reduction of $\mathrm{O}_{2}$ or indirectly by univalent reduction of $\mathrm{O}_{2}$ followed by dismutation of $\mathrm{O}_{2}^{-\cdot}$ [38]. Some pesticides caused an increase in CAT activity [39,40], while a decline in this activity was observed by Babo and Vasseur [41].
Several studies suggest that carbaryl might affect either the biotransformation or oxidative stress defence system in different classes of animals $[2,42,43]$. Our results shown that at 14 days of exposure a metabolic change occurred, which may be due to the generation of reactive species in other metabolic pathway to that one of carbaryl. One of the multiple metabolites resulting from carbaryl degradation could be the responsible for that response. The 1naphtol is the principal metabolite resulting from carbaryl degradation in some biological models, and can induce oxidative stress in the liver and erythrocytes of rats $[44,45]$. The accumulation of this metabolite in significant concentrations between 7 and 14 days of exposure and its degradation products may be the reason for the increase of enzymatic activities observed after 14 days of exposition to carbaryl.

In an oxidative stress situation, it would be normal to observe an increase in GR activity in order to re-establish the levels of GSH that is oxidised [46,47]. The present study shows an increase in the GR activity only in 14th day. On the other hand, the GSH content was rather stable during the exposure period. It may be an evidence that GSH is being synthesized by GSSG reduction and not because its need due to its involvement in other metabolic processes, like participating in ascorbic acid metabolism, maintaining intercellular communication and generally preventing protein-SH groups from oxidizing and cross-linking [20]. The GSH/GSSG ratio is a good indicator of oxidative stress. For example, the GSSG/GSH ratio in contaminated bivalve molluscs from Spanish coast under oxidative stress conditions showed a significant increase [48]. In our case, after 14 days of exposure the GSH/GSSG ratio was higher than the control group, whereas in the remaining periods it was alike the control. In summary, considering a determined biological model, increased enzymatic activities levels are evidence that the antioxidant system is attempting to protect the organism against any damage caused by oxidative stressors [49]. However, in the present study this increase was not observed.

In relation to the histological results, the homogeneous parenchyma of $O$. niloticus liver from control fish was quite similar to that described by Figueiredo-Fernandes et al. [50]. The occasional necrotic foci were not significant in number and frequency. The data concerning the cellular VD did not show significant changes when the fish were exposed to carbaryl. Our results are similar to those obtained by Tos-Luty et al. [51] in rats exposed to carbaryl, in the sense that only slight histological changes were seen.

Fig. 1. Liver antioxidant activities (means $\pm \mathrm{SD}$ ) in Nile tilapia $O$. niloticus $(n=6)$ exposed to sublethal concentrations of carbaryl: $\left(\boldsymbol{\square} 0.25 \mathrm{mg} \mathrm{L}^{-1}\right.$ and $\square$ $0.5 \mathrm{mg} \mathrm{L}^{-1}$ ). The activity levels of treated fish were compared with control group in each sampling day, including recovery group (RG). The control groups values were the following: SOD $4.11 \pm 0.05 \mathrm{U} / \mathrm{mg}$ protein; CAT $4.95 \pm 0.14 \mathrm{U} / \mathrm{mg}$ protein; GST $3.61 \pm 0.03 \mathrm{U} / \mathrm{mg}$ protein; GR $6.49 \pm 0.20 \mathrm{U} / \mathrm{mg}$ protein; GSH-2.74 $\pm 0.03 \mu \mathrm{mol} \mathrm{g}^{-1}$ tissue; GSSG- $0.15 \pm 0.01 \mu \mathrm{mol} \mathrm{g}^{-1}$ tissue; GSH/GSSG was $18.77 \pm 1.52 \mu \mathrm{mol} \mathrm{g}^{-1}$ tissue. [*** $p \leqslant 0.001 ;{ }^{* *} p \leqslant 0.01$; ${ }^{*} p \leqslant 0.05 ;$ ns, not significant]. 

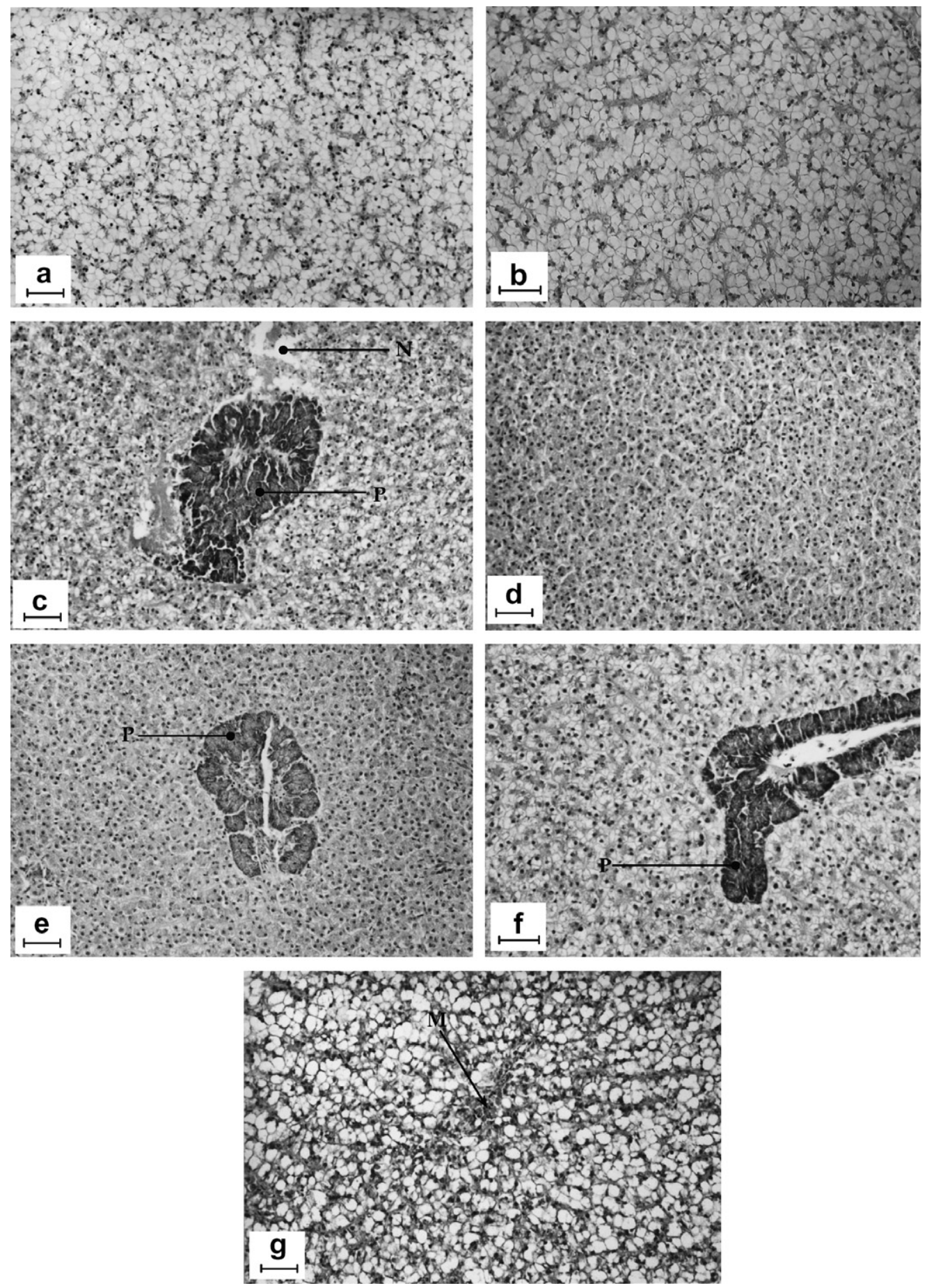

Fig. 2. Histological images of Nile tilapia (Oreochromis niloticus) liver. Control group (a), day 0 group (b) and fish exposed to carbaryl (c-7th day, $0.25 \mathrm{mg} \mathrm{L}^{-1}$; $\mathrm{d}$ - 7 th day, $0.5 \mathrm{mg} \mathrm{L}^{-1}$; e-14th day, $0.25 \mathrm{mg} \mathrm{L}^{-1}$; f-21st day, $0.25 \mathrm{mg} \mathrm{L}^{-1}$; g-recovering group from fish exposed to $0.5 \mathrm{mg} \mathrm{L}^{-1}$ ). The series of images illustrate the gradual increase in the basophilia of the hepatic parenchyma, as seen by the increasingly darker hepatocytes. The darkest areas in the images correspond to exocrine cells of the pancreas, typically surrounding afferent veins $(\mathrm{b}, \mathrm{d}$, and e); exogenous pancreas $(\mathrm{P})$ and necrosis $(\mathrm{N})$; $\mathrm{H} \& \mathrm{E}$, bars $=50 \mu \mathrm{m}$.

In fish exposed to carbaryl it was observed a relation between the parenchyma heterogeneous vacuolization appearance and the duration of exposure, but also a concomitant increase in the hepatocellular basophilia. The combined increased basophilia and loss of hepatic glycogen is a common, although non-specific, liver response to many toxicants [52,53]. Most commonly, the greater cell baso- philia invariably results from an increased relative amount of rough endoplasmic reticulum in the cytoplasm, as previous correlative studies have demonstrated in fish hepatocytes $[52,54,55]$.

This study proved that exposure to sublethal concentrations of carbaryl evoked in Nile tilapia hepatocellular changes suggestive of an adaptive response, for example 
Table 1

The vacuolization degree of the hepatocytes as a function of exposure day and concentration of carbaryl $(n=6)$

\begin{tabular}{llllll}
\hline Day & $\begin{array}{l}\text { Concentration } \\
\left(\mathrm{mg} \mathrm{L}^{-1}\right)\end{array}$ & Minimum & Maximum & Median & Mode \\
\hline Control & 0.25 & 1 & 3 & 3.00 & 3 \\
& 0.5 & 1 & 3 & 3.00 & 3 \\
0 & 0.25 & 1 & 3 & 3.00 & 3 \\
& 0.5 & 1 & 3 & 3.00 & 3 \\
7 & 0.25 & 1 & 3 & 2.50 & 3 \\
& 0.5 & 0 & 3 & 1.50 & 0 \\
14 & 0.25 & 0 & 3 & 2.00 & 3 \\
& 0.5 & 1 & 3 & 2.00 & 2 \\
21 & 0.25 & 2 & 3 & 3.00 & 3 \\
& 0.5 & 2 & 3 & 3.00 & 3 \\
RG & 0.25 & 2 & 3 & 2.50 & 2 \\
& 0.5 & 2 & 3 & 3.00 & 3 \\
\hline
\end{tabular}

as revealed by the glycogen depletion and augmented basophilia. The biochemical data showed there was a very rapid response after the fish contact with the compound. The kinetics of the response was not linear in time, as, for certain biochemical targets we noticed a different behaviour at the day 14 and/or at the day 21 . The results of the recovery data suggest that the toxicity produced by carbaryl is reversible to some extent within 15 days after stimulus withdraw. In conclusion, in this work histological and biochemical changes of liver have been related to carbaryl exposure and concentration, warning for the potentially negative impact of this insecticide for wild fish, especially in case of persistence of contact with carbaryl contaminated water.

\section{Acknowledgment}

The financial support for this project from Centre of Technological, Environmental and Life Studies (CETAV) is gratefully acknowledged.

\section{References}

[1] S. Hardersen, S.D. Wratten, The effects of carbaryl exposure of the penultimate larval instars of Xathocnemis zealandica on emergence and fluctuating asymmetry, Ecotoxicology 7 (1998) 297-304.

[2] D. Ribera, J.F. Narbonne, M. Saint-Denis, Biochemical responses of the earthworm Eisenia fetida andrei exposed to contaminated artificial soil, effects of carbaryl, Soil Biol. Biochem. 33 (2001) 1123-1130.

[3] J.H. Caro, H.P. Freeman, B.C. Thomas, Persistence in soil and losses in run off of soil incorporated carbaryl in a small watershed, J. Agric. Food Chem. 22 (1974) 860-863.

[4] O. Odeyemi, Relative stability of carbaryl in tropical ecosystems, Environ. Pollut. 29 (1982) 207-213.

[5] C.J. Pfeiffer, B. Qiu, C.H. Cho, Electron microscopic perspectives of gill pathology induced by 1-naphthyl- $N$-methylcarbamate in the goldfish (Carassius auratus Linnaeus), Histol. Histopathol. 12 (1997) 645-653.

[6] J.A. Almeida, Y.S. Diniz, S.F.G. Marques, I.A. Faine, B.O. Ribas, R.C. Burneiko, E.I.B. Novelli, The use of the oxidative stress responses as biomarkers in Nile tilapia (Oreochromis niloticus) exposed to in vivo cadmium contamination, Environ. Int. 27 (2002) 673-679.
[7] H. Nivedhitha, P. Thangavel, A.K. Shaik, D.M. Dawood, M. Ramaswamy, Adaptative changes in the patterns of carbohydrate metabolites in blood, liver, muscle and heart tissues of Sarotherodon mossambicus (Peters) exposed to the carbamate fungicide ziram, Pestic. Sci. 52 (1998) 133-137.

[8] P.S. Bhavan, P. Geraldine, Biochemical stress responses in tissues of the prawn Macrobranchium malcolmsonii on exposure to endosulfan, Pestic. Biochem. Physiol. 70 (2001) 27-41.

[9] Y. Sevgiler, E.O. Oruc, N. Uner, Evaluation of etaxozole toxicity in the liver of Oreochromis niloticus, Pestic. Biochem. Physiol. 78 (2004) 1-8.

[10] D.M. Rao, A.S. Murty, P.A. Swarup, Relative toxicity of technical grade and formulated carbaryl and 1-naphtol to, and carbarylinduced biochemical changes in the fish Cirrhinus mrigala, Environ. Pollut. 34 (1984) 47-54.

[11] M. Ramaswamy, P. Thangavel, N. Panneer Selvan, Glutamic oxaloacetic transaminase (GOT) and glutamic pyruvic transaminase (GPT) enzyme activities in different tissues of Sarotherodon mossambicus (Peters) exposed to a carbamate pesticide, carbaryl, Pestic. Sci. 55 (1999) 1217-1221.

[12] A. Ferrari, O.L. Anguiano, J. Soleño, A. Venturino, A.M. Pechen D'angelo, Different succeptibility of two aquatic vertebrates (Oncorhynchus mykiss and Bufo arenarum) to azinphos methyl and carbaryl, Comp. Biochem. Physiol. 139 (2004) 239-243.

[13] R. Triebskorn, H.R. Köhler, J. Flemming, T. Braunbeck, R.D. Negele, H. Rahmann, Evaluation of bis(tri- $n$-butyltin)oxide (TBTO) neurotoxicity in rainbow trout (Oncorhynchus mykiss). I. Behaviour, weight increase, and tin contents, Aquat. Toxicol. 30 (1994) 189-197.

[14] R. Triebskorn, H.R. Köhler, W. Honnen, M. Schramm, S.M. Adams, Induction of heat shock proteins, changes in liver ultrastructure, and alterations of fish behaviour: are these biomarkers related and are they useful to reflect the state of pollution in the field? J. Aquat. Ecos. Stress Recov. 6 (1997) 57-73.

[15] D.E. Hinton, D.J. Laurén, Liver structural alterations accompanying chronic toxicity in fishes: potential biomarkers of exposure, in: J.F. McCarthy, L.R. Shugart (Eds.), Biomarkers of Environmental Contamination, Lewis, Boca Raton, 1990, pp. 17-57.

[16] S. Biagianti-Risbourg, Les perturbations (ultra) structurales du foie des poissons utilisées comme biomarqueurs de la qualité sanitaire des milieux aquatiques, in: L. Lagadic, T. Caquet, J.C. Amiard, F. Ramade (Eds.), Utilisation de Biomarqueurs en Ecotoxicologie, Aspects Fondamentaux, Masson Pub., Paris, 1997, pp. 355-391.

[17] R.T. Di Giulio, P.C. Washburn, R.J. Wenning, G.W. Winston, C.S. Jewell, Biochemical responses in aquatic animals: a review of oxidative stress, Environ. Toxicol. Chem. 8 (1989) 1103-1123.

[18] D.R. Livingstone, P. Garcia-Martinez, X. Michel, J.F. Narbonne, S. O'Hara, D. Ribera, G.W. Winston, Oxyradical generation as a pollution-mediated mechanism of toxicity in the common mussel, Mytilus edulis L and other molluscs, Funct. Ecol. 4 (1990) 415-424.

[19] D. Bagchi, M. Bagchi, E.A. Hassoun, S.J. Stohs, In vitro and in vivo generation of reactive oxygen species, DNA damage and lactate dehydrogenase leakage by selected pesticides, Toxicology 104 (1995) $129-140$.

[20] B. Halliwell, J.M.C. Gutteridge, in: Free Radicals in Biology and Medicine, Oxford University Press, Oxford, 1999, p. 543.

[21] A. Orbea, M. Ortiz-Zarragoitia, M. Solé, C. Porte, M.P. Cajaraville, Antioxidant enzymes and peroxisome proliferation in relation to contaminant body bordens of PAHs and PCBs in bivalve molluscs, crabs and fish from the Urdaibai and Plentzia estuaries (Bay of Biscay), Aquat. Toxicol. 58 (2002) 75-98.

[22] F. Regoli, G. Frenzilli, R. Bochetti, F. Annarumma, V. Scarcelli, D. Fattorini, M. Nigro, Time-course variations of oxyradical metabolism, DNA integrity and lysossomal stability in mussels, Mytilus galloprovincialis, during a filed translocation experiment, Aquat. Toxicol. 68 (2004) 167-178.

[23] A.A. Fontaínhas-Fernandes, Tilapia production, in: M.A. ReisHenriques (Ed.), Aquaculture Handbook, 1998, pp. 135-150.

[24] A.A. Fontaínhas-Fernandes, E. Gomes, M.A. Reis-Henriques, J. Coimbra, Replacement of fish meal by plant proteins in the diet of 
tilapia (Oreochromis niloticus): digestibility and growth performance, Aquacult. Int. 7 (1999) 57-67.

[25] M. Payá, B. Halliwell, J.R.S. Hoult, Interactions of a series of coumarins with reactive oxygen species, Biochem. Pharmacol. 44 (1992) 205-214.

[26] I. Carlberg, B. Mannervik, Glutathione reductase, Meth. Enzymol. 113 (1985) 484-490.

[27] I.K. Smith, T.L. Vierheller, C.A. Thorne, Assay of glutathione reductase in crude tissue homogenates using 5, 5'-dithiobis(2-nitrobenzoic acid), Anal. Biochem. 175 (1988) 408-413.

[28] W.H. Habig, J. Pabst, W.B. Jakoby, the first enzymic step in mecapturic acid formation, J. Biol. Chem. 249 (1974) 7130-7139.

[29] C. Uguz, M. Iscan, A. Ergüven, B. Isgor, I. Togan, The bioaccumulation of nonyphenol and its adverse effect on the liver of rainbow trout (Oncorhynchus mykiss), Environ. Res. 92 (2003) 262-270.

[30] P.J. Hissin, R. Hilf, A fluorometric method for determination of oxidized and reduced glutathione in tissues, Anal. Biochem. 74 (1976) 214-226.

[31] E. Beutler, Red Cell Metabolism: A Manual Biochemical Methods, second ed., Grune and Starton, New York, 1984.

[32] M.M. Bradford, A rapid and sensitive method for the quantification of microgram quantities of protein utilizing the principle of proteindye binding, Anal. Biochem. 72 (1976) 248-254.

[33] A. Figueiredo-Silva, E. Rocha, J. Dias, P. Silva, P. Rema, E. Gomes, L.M.P. Valente, Partial replacement of fish oil by soybean oil on lipid distribution and liver histology in European sea bass (Dicentrarchus labrax) and rainbow trout (Oncorhynchus mykiss) juveniles, Aquacult. Nutr. 11 (2005) 147-155.

[34] B.D. Banerjee, V. Seth, R.S. Ahmed, Pesticide-induced oxidative stress: perspectives and trends, Rev. Environ. Health 16 (2001) 1-40.

[35] H. Durmaz, Y. Sevgiller, N. Üner, Tissue-specific antioxidative and neurotoxic responses to diazinon in Oreochromis niloticus, Pestic. Biochem. Physiol. 84 (2006) 215-226.

[36] Z. Yuan, M. Wirgin, S. Courtenay, M. Ikonomou, I. Wirgin, Is hepatic cytochrome P4501A1 expression predictive of hepatic burdens of dioxins, furans, and PCBs in Atlantic tomcod from the Hudson River estuary? Aquat. Toxicol. 54 (2001) 217-230.

[37] S.C. Courtenay, C.M. Grunwald, G.-L. Kreamer, W.L. Fairchild, J.T. Arsenault, M. Ikonomou, I.I. Wirgin, A comparison of the dose and time response of CYP1A1 mRNA induction in chemically treated Atlantic tomcod from two populations, Aquat. Toxicol. 47 (1999) 43-69.

[38] I. Fridovich, Oxygen radicals, hydrogen peroxide, and oxygen toxicity, in: W.A. Pryor (Ed.), Free Radicals in Biology, Academic Press, London, 1976, pp. 239-277.

[39] V.B.C. Jungueira, K. Simizu, L.V. Halsema, O.R. Koch, S.B.M. Bários, A.L. Videla, Lindane-induced oxidative stress. I. Time course of changes in hepatic microsomal parameters, antioxidant enzymes, lipid peroxidative indices and morphological characteristics, Xenobiotica 18 (1988) 1297-1304.

[40] E.O. Oruc, Y. Sevgiller, N. Uner, Tissue-specific oxidative stress responses in fish exposed to 2,4-D and azinphosmethyl, Comp. Biochem. Physiol. 137 (2004) 43-51.

[41] S. Babo, P. Vasseur, In vitro effects of thiram on live antioxidant enzyme activities of rainbow trout (Oncorhynchus mykiss), Aquat. Toxicol. 22 (1992) 6168-6173.
[42] K.S. Rao, K.R. Rao, Effect of sublethal concentration of methyl parathion on selected oxidative-enzymes and organic constituents in the tissues of the freshwater fish, Tilapia mossambica (Peters), Curr. Sci. 4 (1979) 526-528.

[43] A. Rajyalakshmi, T.G. Reddy, Effect of carbaryl and lindane on the lipid content of maternal tissues and embryos of the viviparous scorpion, Heterometrus fulvipes (Koch), J. Environ. Biol. 9 (1988) 97 105.

[44] I.I. Pavlova, O.G. Petrovskaya, S.I. Ivanova, Biochemical and histochemical studies on the oxidative-reductive enzymes after an exposure to Sevin, Gig. Primen. Toxicol. Pestic. Klin. Otrav. (1968) 625-630.

[45] E.J. Calabrese, C.P. Geiger, Low erythrocyte glucose-6-phosphate dehydrogenase (G-6-PD) activity and susceptibility to carbaryl induced methemoglobin formation and glutathione depletion, Bull. Environ. Contam. Toxicol. 36 (1986) 506-509.

[46] A. Figueiredo-Fernandes, A. Fontaínhas-Fernandes, F. Peixoto, E. Rocha, M.A. Henriques, Effects of gender and temperature on oxidative stress enzymes in Nile tilapia Oreochromis niloticus exposed to paraquat, Pest. Biochem. Physiol. 85 (2006) 97-103.

[47] F. Peixoto, D. Simões, D. Santos, A. Fontaínhas-Fernandes, Toxicological effects of oxyfluorfen on oxidative stress enzymes in tilapia Oreochromis niloticus, Pest. Biochem. Physiol. 85 (2006) 91-96.

[48] A. Rodriguez-Ariza, N. Abril, J.I. Navas, G. Dorado, J. LópezBarea, C. Pueyo, Metal mutagenicity, and biochemical studies on bivalve molluscs from Spanish coasts, Environ. Mol. Mutagen. 19 (1992) 112-124.

[49] A. Rodriguez-Ariza, J. Peinado, C. Pueyo, J. López-Barea, Biochemical indicators of oxidative stress in fish from polluted littoral areas, Can. J. Fish. Aquat. Sci. 50 (1993) 2568-2573.

[50] A. Figueiredo-Fernandes, A. Fontaínhas-Fernandes, R.A.F. Monteiro, M.A. Reis-Henriques, E. Rocha, Temperature and gender influences on the hepatic stroma (and associated pancreatic acini) of Nile tilapia Oreochromis niloticus (Teleostei, Cichlidae); A stereological analysis by light microscopy, J. Morphol. 267 (2006) 221-230.

[51] S. Tos-Luty, D. Przebirowska, J. Latuszynska, M. Tokarska-Rodak, Histological and ultrastructural studies of rats exposed to carbaryl, Ann. Agric. Environ. Med. 8 (2001) 137-144.

[52] J.C. Wolf, M.J. Wolfe, A brief overview of nonneoplastic hepatic toxicity in fish, Toxicol. Pathol. 33 (2005) 75-85.

[53] A. Figueiredo-Fernandes, A. Fontaínhas-Fernandes, R. Monteiro, M.A. Reis-Henriques, E. Rocha, Effects of the fungicide mancozeb on liver structure of Nile tilapia, Oreochromis niloticus - assessment and quantification of induced cytological changes using qualitative histopathology and the stereological point-sampled intercept method, Bull. Environ. Contam. Toxicol. 76 (2006) 249-255.

[54] D.E. Hinton, Toxicologic histopathology of fishes: a systematic approach and overview, in: J.A. Couch, J.W. Fournie (Eds.), Pathobiology of Marine and Estuarine Organisms, CRC Press, Boca Raton, Florida, 1993, pp. 177-215.

[55] E. Rocha, R.A.F. Monteiro, Histology and cytology of fish liver: a review, in: D.N. Saksena (Ed.), Ichthyology: Recent Research Advances, Science Publishers Inc., Enfield, New Hampshire, 1999, pp. 321-344. 